\title{
KE 40. VÝROČÍ VYDÁNÍ MUZEOLOGICKÉHO SLOVNÍKU JOSEFA BENEŠE

\section{VÁCLAV RUTAR}

Muzeologie se po celou dobu své existence potýká s terminologickými problémy. V zásadních muzeologických pracích, vezmeme-li v potaz ty, které vznikly jako první na území naší republiky (Jiří Neustupný, 1950; Zbyněk Z. Stránský, 1972), není ještě vzniku slovníků věnována pozornost a neděje se tak v porovnání s archivnictvím, knihovnictvím či památkovou péčí ani v zahraničí. Terminologie je jako mezinárodní muzeologický úkol určena na 7. generální konferenci ICOM v New Yorku v roce 1965, ovšem jednání je následně po více jak 10 let značně roztříštěno. $S$ počátkem mezinárodní práce je tak spojována až rezoluce $\mathrm{z}$ moskevské konference $\mathrm{v}$ roce 1977 , kdy vzniká pracovní skupina, které se v roce 1986 podaří vydat konečnou podobu očekávaného slovníku Dictionarium Museologicum. Je však nutno připomenout, že v zápisech z jednání jsou zmiňovány již čtyři existující - německý, ruský, slovenský a - český, dnes již 40 let starý Muzeologický slovník Josefa Beneše.

\section{Historie mezinárodní práce na muzeologické terminologii}

„Předpokladem úspěšného rozvoje kteréhokoli oboru je mj. i ujasnění terminologického aparátu, který umožňuje dorozumívání na žádoucí úrovni a vylučuje užívání termínů $v$ nejasném obsahovém pojetí."1 $\mathrm{V}$ roce 1986 takto Josef Beneš popisuje smysl zpracování terminologie

1 BENEŠ, Josef. Úvod do problematiky muzeologické terminologie. Metodický zpravodaj pro vlastivědu v Severomoravském kraji - Muzeologie 10, 1986, s. 3.

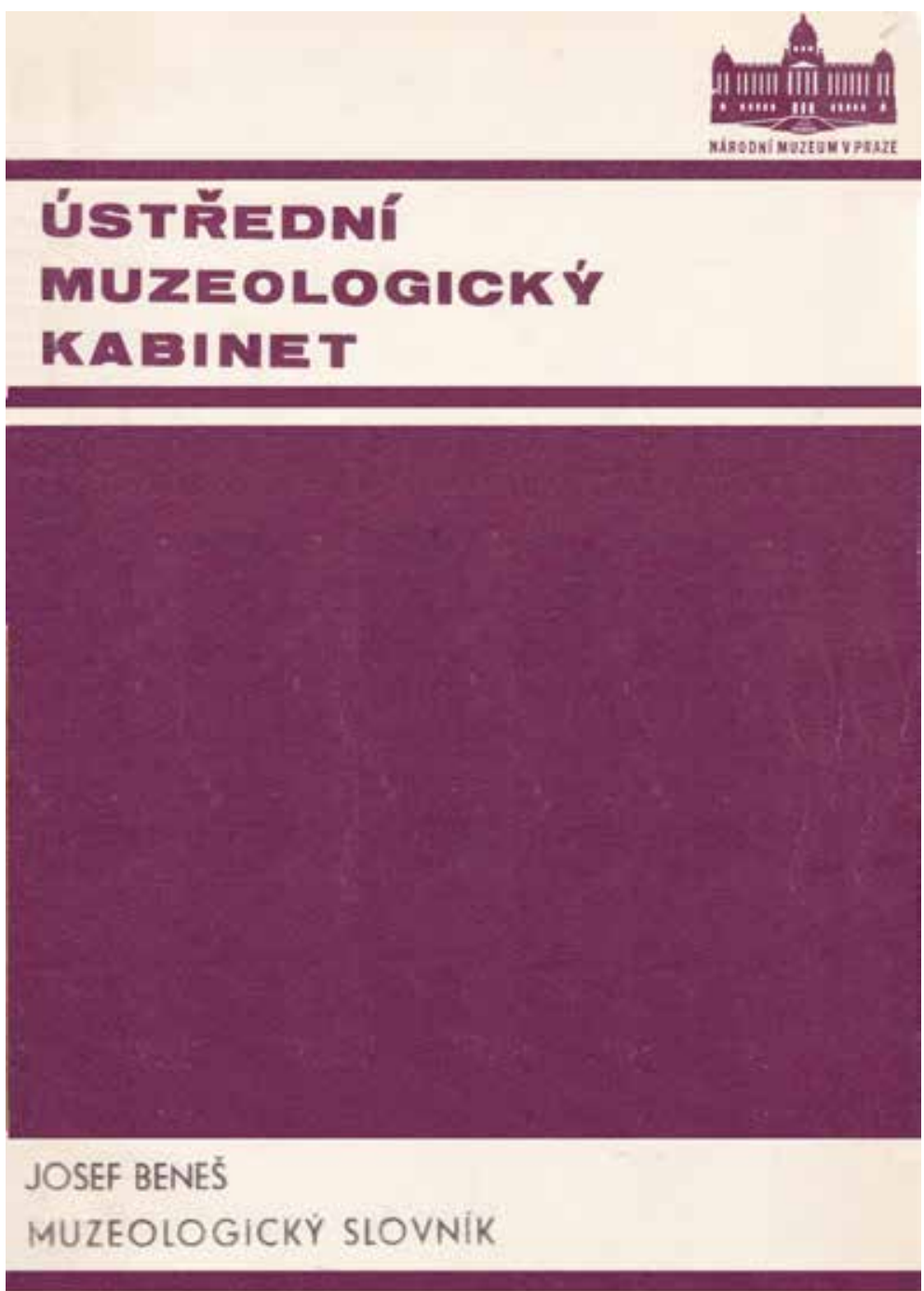

oborů, které stále ještě bojují o přijetí za vědu a mezi něž v té době jistě patřila stále i muzeologie. Ponecháme-li stranou nejasnosti o stálém hledání pravého předmětu a systematiky, jeví se prvotní práce na muzeologické terminologii v letech 1965-1986 jako nejčastěji řešený teoretický problém.
Na 7. generální konferenci ICOM v New Yorku v roce 1965 byl poprvé předložen úkol práce na dokumentaci/terminologii UNESCO-ICOM Museum Documentation Centre spolu s CIDOCem (International Committee for Documentation). V první fázi byl volen způsob využití desetinného třídění, od kterého se však později odstoupilo. 

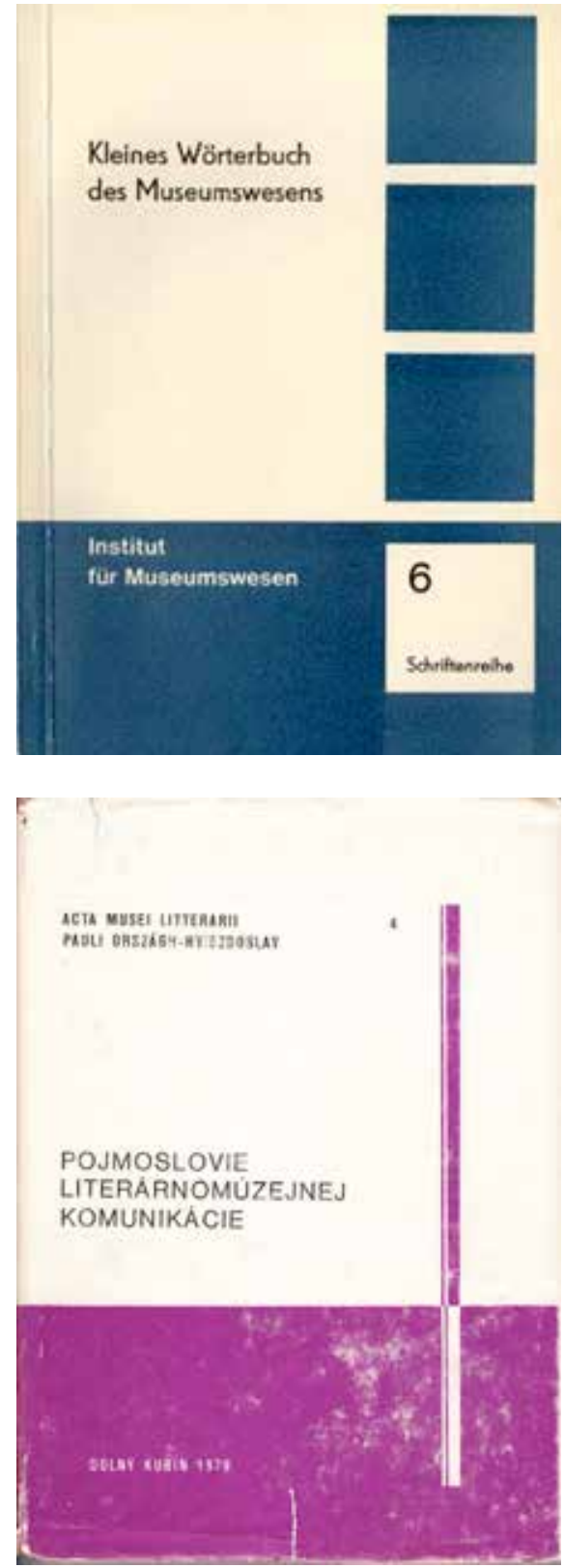

Hlavní pracovní skupina byla vedena polským muzeologem Jerzy Banachem a Václavem Pubalem z pražského Národního muzea. ${ }^{2}$ $\mathrm{V}$ rámci rezolucí z konference

2 Václav Pubal vedl od roku 1956 do roku 1980 Kabinet muzejní a vlastivědné práce při Národním muzeu v Praze (od r. 1969 Muzeologický kabinet, od r. 1973 Ústřední muzeologický kabinet). Vedle své práce v pracovní skupině pro terminologii, která se později orientovala na muzeologickou bibliografii, je i autorem úvodu do Benešova Muzeologického slovníku, kde jej uvádí jako předběžný a provizorní, což ovšem často není pochopeno a vede ke zbytečné negativní kritice. K Pubalovi viz např. https://cs.wikipedia.org/ wiki/Ústřední_muzeologický_kabinet. $\mathrm{v}$ roce $1968^{3}$ se tvorbou muzeologického slovníku měly začít zabývat národní komitéty - klasifikace, svázané $\mathrm{s}$ bibliografií byly $\mathrm{v}$ roce 1970 na konferenci CIDOC v Praze představeny $\mathrm{v}$ českém, ruském, polském a německém jazyce, o rok později bylo v rámci jednání téhož komitétu ${ }^{4}$ rozhodnuto zaměřit se dále i na francouzský a anglický jazyk coby oficiální pro ICOM.

Zlomovým bodem ve vývoji mezinárodních snah o muzeologickou terminologii byla ustanovení z 11. generální konference ICOM v Moskvě, především pak konkrétní rezoluce č. 7. - „Museological Terminology“". ${ }^{5}$ Nově vytvořená pracovní skupina, $v$ jejímž čele stál István Éri, již záhy vypracovala první vydání Dictionarium Museologicum (1978). ${ }^{6}$ Slovník obsahoval 1560 termínů ve čtyřech jazycích (mad’arština, angličtina, francouzština, němčina), ne vždy však zahrnoval všechny potřebné ekvivalenty. Práce na slovníku pokračovala až do roku 1986, kdy byla $\mathrm{v}$ souladu $\mathrm{s}$ předloženým úkolem představena poslední verze Dictionarium Museologicum s 1632 termíny na 14 . generální konferen-

3 Jednalo se o 4. rezoluci z 8. generální konference, která se odehrála v Německu v Mnichově a Kolíně nad Rýnem.

4 CIDOC (International Committee for Documentation) - jednání proběhlo v rámci 9. Generální konference ICOM v Paříži.

5 Čteme-li část „...necessary to define museological terms as an important contribution to the better mutual understanding between museum professionals in different countries...", tak nelze nevidět, že je téměř obdobná Benešově větě z roku 1986 (viz pozn. 1). Moscow 1977: 12th General Assembly of ICOM. Moscow, USSR, 28 May 1977. In ICOM International Council of Museums [online]. ICOM 2010-2018 [cit. 2018-06-20]. Dostupný z www: <http:// icom.museum/the-governance/general-assembly/ resolutions-adopted-by-icoms-general-assemblies1946-to-date/moscow-1977/>

6 Vývoj slovníku Dictionarium Museologicum je detailně popisován v Newsletter of Museological Terminology, který vycházel pravidelně mezi lety 1979-1986. Rozsáhlému popisu vývoje se věnují i Muzeologické sešity, viz BRŮŽA, Oskar a Zbyněk Z. STRÁNSKÝ. Zrod muzejní terminologie. Muzeologické sešity X/86, 1986, s. 137-172. Do tvorby slovníku byly za tehdejší ČSSR nejblíže zapojeni Zbyněk Z. Stránský, Oskar Brůža. Z významných zahraničních muzeologů zmiňme např. Friedricha Waidachera, Zoltána Vadkertiho, Villyho Tofta Jensena, Wilhelma Ennenbacha či Jurije Piščulina. ci ICOM v Buenos Aires. ${ }^{7}$ Během prríprav prošla práce mnoha obměnami - abecední řazení termínů bylo nahrazováno pokusy o bližší klasifikaci a nové klasifikační schéma, pojmy byly děleny systematicky do hierarchicky uspořádaných skupin, zvětšoval se počet jazyků. Konečný výstup byl „pouze“ dvacetijazyčným abecedně řazeným překladovým slovníkem bez výkladu vybraných termínů. ${ }^{8} \mathrm{~V}$ roce 1986 hodnotí Zbyněk Z. Stránský terminologickou činnost popisovaného období následujícím způsobem: „Terminologie není vlastním cílem teoretického úsilí, ale nástrojem rozvoje vědy a mezinárodní výměny informací. Diváme-li se na obrovské úsilí, vynaložené $v$ průběhu posledních dvaceti let na budování naší odborné terminologie, nemůžeme být zcela spokojeni.“9 Přestože je Dictionarium Museologicum největším dílem popisovaného období, ${ }^{10} \mathrm{mi}$ nimálně co do rozsahu, bylo mezi lety 1973-1983 vydáno několik národních muzeologických slovníků, nahlížejících na pojednání terminologie jinak - přinášely výklady jednotlivých pojmů převážně v rámci jednoho jazyka.

\section{Výkladové muzeologické slovní- ky z období 1973-1983}

V pozadí historických snah o muzeologickou terminologii stojí často v pozadí mezinárodního Dictionarium Museologicum slovníky, vydané skupinami odborníků či přímo jednotlivci několika států. Čtyři nejčastěji zmiňované vyšly ještě v 70. letech 20. století. Patří sem německý Kleines Wörterbuch des

\footnotetext{
7 Dictionarium Museologicum. Budapest: Hungarian Esperanto Association, 1986.

8 Před vydáním byly zpracovány výkladové slovníky jen v češtině, němčině a holandštině, které se nakonec podařilo do DM prosadit.

9 BRŮŽA, Oskar a Zbyněk Z. STRÁNSKÝ. Zrod muzejní terminologie. Muzeologické sešity X/86, 1986, s. 153.

10 Které je třeba však výrazně odlišit od následujících snah především francouzských muzeologů, působících v mezinárodním komitétu pro muzeologii (ICOFOM). Terminologické práce komitétu pro muzeologii ale nejsou tématem tohoto článku.
} 
Museumswesens (dále KWM), který byl po částečném publikování v letech 1973 a 1974 představen roku 1975, ${ }^{11}$ Kratkij slovar muzejnych terminov (KS), vydaný v Moskvě $\mathrm{v}$ roce $1974,{ }^{12}$ český Muzeologický slovník Josefa Beneše $\mathrm{z}$ roku $1978^{13}$ a konečně terminologicky specializovaná slovenská publikace Pojmoslovie literárnomúzejnej komunikácie (PLK) z roku 1979. ${ }^{14}$ Do sledovaného období je možno zařadit i práci Museologische Termini-Auswahl (MTA) Klause Schreinera, vydanou v roce $1982,{ }^{15}$ a konečně i nepříliš známý slovník holandských termínů od Petera van Mensche Museologische woordenboek $\mathrm{z}$ roku 1983 . $^{16}$

Do sledovaného období je možno zařadit i několik monografií. Z českých je to především Stránského Úvod do studia muzeologie, vydaný $\mathrm{v}$ roce $1980,{ }^{17}$ ze zahraničních je nejčastěji zmiňován Introduction to Museum Work od G. Ellise Burcawa $\mathrm{z}$ roku $1976 .{ }^{18}$

11 Kleines Wörterbuch des Museumswesen. Berlin: Institut für Museumswesen, 1975.

\section{Kratkij slovar muzejnych terminov. Moskva,} 1974.

13 BENEŠ, Josef. Muzeologický slovník. Praha: Národní muzeum - Ústřední muzeologický kabinet, 1978.

14 Pojmoslovie literárnomúzejnej komunikácie. Dolný Kubín - Nitra, 1979. Této publikaci předchá zel ještě Terminologický slovník literárnomúzejnej komunikácie z roku 1977, který byl zmiňovanou knihou dopracován.

15 SCHREINER, Klaus. Museologische TerminiAuswahl. Neubrandenburg, 1982.

16 Peter van Mensch představuje svůj slovník v Newsletter of Museological Terminology, 1983/4/7-10 pod názvem Nederlandse museumterminologie. Uvedený název Museologische Woordenboek pochází z jeho práce Towards a methodology of museology z roku 1992, viz Museological terminology. In MENSCH, Peter van. Towards a methodology of museology. Zagreb: University of Zagreb, 1992. PhD. thesis [online]. [cit. 2018-0620]. Dostupný z www: <http://vana.muuseum.ee/ uploads/files/mensch08.html>.

17 STRÁNSKÝ, Z. Zbyněk. Úvod do studia muzeologie. Brno: Rektorát UJEP, 1980

18 BURCAW, G. Ellis. Introduction to Museum Work. Nashville: American Association for State and Local History, 1975. Recenzi ke knize G. Ellise Burcawa zpracoval Zbyněk Z. Stránský v Muzeologických sešitech. STRÁNSKÝ, Z. Zbyněk. G. E. Burcaw: Introduction to Museum Work. Muzeologické sešity VII/79, 1979, s. 152-154.

Z brněnských muzeologických diplomových prací
KWM z roku 1973 (1975) je zpracován kolektivem Rolfa Kiaua a díky delší přípravě se $\mathrm{k}$ němu mohlo vyjádřit kolem 80 muzejníků, německých i zahraničních. ${ }^{19}$ Slovník tvoří celkem 282 hesel, která jsou řazena abecedně a je směrován jen na termíny teorie muzejnictví - proto je též relativně málo rozsáhlý. Je to však - jak je později uváděno i u ostatních slovníků z tohoto období - „solidní východisko“. Sovětský KS, který vyšel v roce 1974 po spolupráci rozsáhlé skupiny muzejníků, ${ }^{20}$ obsahuje 211 hesel, seřazených abecedně. Každý z termínů je stručně vymezen - autoři vychází zejména z muzejní literatury, ale i z muzejní praxe. KS byl vydán i v překladu a přepisu do latinky v Metodickém listu M/1/1978 brněnského Metodicko-muzeologického oddělení Moravského muzea v Brně. ${ }^{21}$ Specializovanou práci PLK zpracovalo ve spolupráci s brněnskými muzeology Literárné múzeum p. o. Hviezdoslava v Dolnom Kubíne v roce 1979. Literární část se v díle pojí s muzeologickým přístupem. Dochází k systémovému

je dále možno zmínit též Př́spěvky $k$ sjednocování oborové terminologie Oskara Brůži z roku 1978. BRŮŽA, Oskar. Příspěvky k sjednocování oborové terminologie. Brno: Filozofická fakulta University Jana Evangelisty Purkyně, 1978. Závěrečná práce postgraduálního studia muzeologie.

19 Z českých muzeologů se k německému slovníku ve svých pracích vyjadřuje Zbyněk Z. Stránský, kritice jej vystavuje v Muzeologických sešitech společně s Oskarem Brůžou. Srov. BRŮŽA Oskar a Zbyněk Z. STRÁNSKÝ. Zrod muzejní terminologie. Muzeologické sešity X/86, 1986 s. 139; BRŮŽA, Oskar a Zbyněk Z. STRÁNSKY. Kleines Wörterbuch des Museumswesens. Muzeologické sešity VI/76, 1976, s. 207-212. Informace o německém slovníku přináší i monografie Zbyňka Z. Stránského. STRÁNSKÝ, Z. Zbyněk. Úvod do studia muzeologie. Brno: Rektorát UJEP, 1980, s. 36.

20 Ve skupině zpracovatelů slovníku působil např. A. B. Zaks, A. M. Razgoň a J. Piščulin. Nejrozsáhleji se sovětskému slovníku věnuje opět Zbyněk Z. Stránský s Oskarem Brưžou, srov. BRŮŽA, Oskar a Zbyněk Z. STRÁNSKÝ. Zrod muzejní terminologie. Muzeologické sešity $X / 86$, 1986, s. 138-139. Stručný popis slovníku je zpracován i v monografii Zbyňka Z. Stránského, srov. STRÁNSKÝ, Z. Zbyněk. Úvod do studia muzeologie. Brno: Rektorát UJEP, 1980, s. 35-36.

21 Stručný popis slovníku je zpracován i v monografii Zbyňka Z. Stránského, srov. STRÁNSKÝ, Z. Zbyněk. Úvod do studia muzeologie. Brno: Rektorát UJEP, 1980, s. 35-36. Překlad slovníku viz Metodický list M/1/1978. Brno: Moravské muzeum v Brně, 1978. uspořádání termínů, čímž se tato práce stává první publikací svého druhu. ${ }^{22}$ Slovník je dělen do dvou hlavních částí (Základní pojmy a Literárněmuzejní prezentace $\mathrm{v}$ komunikaci), které jsou dále rozčleněny a připojen je abecední seznam pojmů. ${ }^{23}$ MTA Klause Schreinera je vydán v roce 1982 (a revidován pak roku 1989) samostatně - Schreiner při výkladu téměř 500 hesel vychází již ze slovníků vydaných, ale uplatňuje částečně i své odlišné pojetí. Stejný přístup volil v roce 1978 i Josef Beneš ve svém Muzeologickém slovníku.

\section{Josef Beneš - Muzeologický slov- ník z roku 1978}

$\mathrm{V}$ tomto roce uplynulo již 40 let od vydání jedné ze zásadních muzeologických prací, citované dodnes v muzeologické literatuře. V roce 1978 vyšel péčí Ústředního muzeologického kabinetu při Národním muzeu v Praze Muzeologický slovník z pera Josefa Beneše. Autor zařadil slovník mezi několik monografií, které se mu podařilo zpracovat a vydat mezi lety 1977-1981. ${ }^{24}$

V Benešově díle, lze již od počátku 70. let 20. století sledovat orientaci $\mathrm{k}$ problematice roztřrištěné terminologie oboru. V roce 1970 publikuje v Muzejní a vlastivědné práci (MVP) rozbor pojmů muzejní - muzeální muzeologický - muzeografick ${ }^{25}$

22 Podobný př́istup se Stránský snaží v té době uplatnit i v rámci spolupráce na mezinárodním slovníku Dictionarium Museologicum.

23 Kritiku slovníku podává Josef Beneš - vysoko hodnotí především interdisciplinární pojetí a princip systematického zpracování, které by dle něj mohly převzít i mnohé další obory, spojené s muzejní prací. Vysoké nároky v oblasti muzeologické a lexikologické (výběr termínů komunikát, gnóm, konotace atd.) nahlíží však spíše negativně, absentuje mnohdy bližší vysvětlení. Srov. BENEŠ, Josef. Terminologický slovník literárně muzejní komunikace. Muzejní a vlastivědná práce, 1980/1, s. $50-51$.

24 V roce 1977 byla vydána monografie Muzeum a sbírky, následující rok Muzeologický slovník, roku 1980 vychází tématicky Benešovi blízká kniha Muzeum a výchova a o rok později závěrečný titul Muzejní prezentace.

25 BENEŠ, Josef. Muzejní, muzeální, muzeolo gický, muzeografický. Muzejní a vlastivědná práce, $1970 / 4$, s. $171-172$. 
a obdobnému tématu se věnuje i o 6 let později. ${ }^{26}$ Významným termínem je pro Beneše muzejní sbírkový předmět a terminologii v souvislosti s ním rozpracovává kromě několika článků i v jedné $\mathrm{z}$ monografií. ${ }^{27} \mathrm{~V}$ obecné rovině se autor ve své bohaté publikační činnosti v dobových muzeologických periodikách zabývá i dalšími konkrétními pojmy (např. aktivizace, animace, dynamizace práce muzea, scénář, audiovizuální prostředky, exponát, etika ad.).

Muzeologický slovník je vyvrcholením dílčí terminologické práce - je prvním dílem, kde je tato otázka zpracována jedním autorem. ${ }^{28}$

Josef Beneš reaguje jak na podněty z literatury, ${ }^{29}$ tak z vlastní odborné práce. Slovník obsahuje 411 abecedně řazených termínů a předchází mu úvod Václava Pubala. Ve své třístránkové předmluvě Pubal uvádí přetrvávající problémy oboru muzeologie a jeho terminologie, kde odkazuje především na otázku mezinárodní s tím, že se v nejbližší době nedá předpokládat vznik slovníku na mezinárodní platformě. ${ }^{30}$

26 BENEŠ, Josef. Příspěvek k diskuzi o muzejním sbírkovém předmětu. Časopis NM-HM, 1967/2, s. 95-100; BENEŠ, Josef. Muzeum, muzejnictv a muzeologie. Muzejní a vlastivědná práce, 1976/4, s. $14-21$.

27 BENEŠ, Josef. Muzeum a sbírky. Praha: Ústav pro řízení a informace v kultuře, 1977. Konkrétn statě viz BENEŠ, Josef. Kulturní statek, kulturní památka a muzejní předmět. Muzejní a vlastivědná práce, 1976/4, s. 90-99; BENEŠ, Josef. Muzeálny predmet a dokumentácia súčasnosti. Múzeum, 1977/1, s. 25-38; BENEŠ, Josef. Poznámky k ujasňování povahy muzejního sbírkového předmětu. Muzejní a vlastivědná práce, 1983/2, s. 83-91.

28 Kritika slovníku je zpracována v Muzeologických sešitech. ŠULER̆, Petr. J. Beneš: Muzeologický slovník. Muzeologický sešity VII/79, 1979, s. 151-152. Šuleř zde uvádí mnohé formální nedostatky (definování víceméně v české muzeologické literatuře nepoužívaných termínů, hypotetický subjektivní přístup $\mathrm{k}$ definici některých pojmů chyby $\mathrm{v}$ abecedním řadění termínů, záměny exponát-expozice, s. 35).

29 Je však nutno zmínit, že zpracování několika nepoužívaných termínů (shodných s některými českými) slovníku spíše škodí. Srov. STRÁNSKÝ, Z. Zbyněk. Úvod do studia muzeologie. Brno: Rektorát UJEP, 1980, s. 36-37.

30 Zde vychází Václav Pubal nejspíše z vlastních zkušeností z vedení pracovní skupiny, která byla sestavena po 7. generální konferenci ICOM v roce
Popisuje slovník jako přednostně muzeologický, nikoli šířeji pojatý muzejní. ${ }^{31}$ Nakonec předkládá i informaci o zpracování hesel (uvádění autorů jen u některých hesel, nezmiňování $\mathrm{k}$ heslům příslušných statí a publikací či omezené přidělení cizojazyčných ekvivalentů) a slovník řadí mezi práce zpracované předběžně a provizorně právě z potřeby další odborné diskuze. V souvislosti s tím je třeba uvést, že slovník vyšel v omezeném počtu 100 kusů.

Prohlédneme-li si zpracovaná hesla, můžeme je dělit do několika skupin - Beneš zpracovává termíny, které se vážou k muzejnímu managementu (ředitel muzea, řízení muzea, statut muzea, systemizace personální), muzejní prezentaci (aktivizace, animace, aranžmá, diorama, efektivita, etiketáž, funkčnost, instalace, osvětlení, percepce, pozvánky, prezentace muzejní, průvodce, putovka, reagování, rekreativní působení, scénář, únava, uživatelé, vizuální vnímání, vitrina, výstava, zpřístupnění), sbírkovému předmětu (akvizice, artefakt, autenticita, dar, darování, dermoplastický preparát, exponát, falzum, hodnota, kolekce, maketa, mentefakt, muzeálie, naturfakt, přírůstek, relikt, sbírka muzejní), typům muzeí (např. archeologické, dopravní, etnologické, galerie, literární, památník, pinakotéka, skanzen, technické, typ muzea, vojenské, zemědělské), bezpečnosti (depozitář, klimatizace, ochrana sbírek, prevence, temperatura, vlhkost relativní, záchrana kulturních statků), souvisejícím oborům (archivnictví, knihověda, kronikářství, monumentika, odbor v muzeu, ochrana přírody, památková péče), konkrétní muzejní práci

1965 v New Yorku a její činnost nebyla úspěšná. Zajímavé je, že v roce 1978 již začala pracovní skupina nová, zaměřená právě na mezinárodně orientovaný slovník Dictionarium Museologicum, a Pubal její činnost zmiňuje.

31 Tj. slovník, postihující obor muzejnictví vcelku (např. včetně termínů pro sbírky v muzeu, historii muzejnictví ad.). (deskripce, dokumentace, evidence, identifikace, inventarizace, katalogizace, konzervace, popis, restaurování, revize, selekce, skartace, substituce, vyřazování, vývoz), práci s návštěvníkem (doprovod, dotazník, edukátor, komunikace, propagace, public relations, vernisáž, veřejnost, vstupenka, výchova, výklad) a odborné teoretické práci a obecným označením (koncepce, kurs, kurátor, kustod, muzeum, muzealita, muzeografie, muzeologie, nákup sbírek, ostenze, poradní sbor, převod, statistika, tezaurus, UNESCO, výuka muzeologie, zákon muzejní, zásady rozvoje muzejnictví).

Uvádím pouze některá ze srozumitelných hesel - Josef Beneš do slovníku zařadil i takové termíny, o jejichž využití v české muzeologické terminologii lze pochybovat, zpravidla počeštění francouzských slov (např. afiš, akrošáž, deparazitář, gidáž, kodáž, mesáž, numerotáž, storáž). Na místech, kde přímého překladu není použito, získáváme naopak cenné informace o znění termínu v jiných jazycích (němčině, angličtině, ruštině). $V$ několika případech jsou hesla propojena, což je určitě přínosem - kdyby bylo tohoto způsobu více využito, slovník by vedle abecedního řazení získal i určitou systematičnost. ${ }^{32}$ Beneš též na několika místech odkazuje $\mathrm{k}$ autorům, kteří se vybranými termíny zabývají - vybírá však pouze muzeology a oborově směřované muzejníky české a slovenské (R. Suk, Z. Zastávka, J. Jelínek, J. Neustupný, K. Sklenář, Z. Z. Stránský, J. Beneš, A. Gregorová, J. Špét, V. Denkstein, V. Vinter, M. Malý, V. Pubal, J. Pavel, L. Kunz, J. Vařeka, M. Nováková, Z. Vašíček, K. Tuček, V. Tkáč). ${ }^{33}$ U typů muzeí uvádí i konkrétní příklady.

32 Jako toho bylo dosaženo u slovenského slovníku, srov. Pojmoslovie literárnomúzejnej komunikácie. Dolný Kubín - Nitra, 1979.

33 Beneš u termínů de facto vyjmenoval všechny významné české muzeology a muzejníky dané doby s tím, že nejčastěji logicky odkazuje k Jiřímu Neustupnému, Zbyňku Z. Stránskému a Josefu 
V roce 1978 je Josef Beneš stále činný na Ministerstvu kultury, což se odráží ve slovníku v poměrně detailně rozpracovaných pojmech, které se váží $\mathrm{k}$ zákonným úpravám a administrativní práci v oblasti muzejnictví. $\mathrm{V}$ obecné rovině je pojednáno archivnictví, ${ }^{34}$ ochrana prírody, ${ }^{35}$ památková péče, $s$ kterou se vážou např. i památníky. ${ }^{36}$ Již k muzejnictví se vážou následující pojednané termíny - Ministerstvo kultury ČSR, ${ }^{37}$ odbor kultury KNV, ${ }^{38}$ organizace muzejnictví, ${ }^{39}$ koncepce muzejnictví, ${ }^{40}$ řízení muzejnictví. ${ }^{41}$

Konkrétní odborné činnosti s muzejními předměty, která vyžaduje spojení s externími orgány či odborníky, se blíže věnuje autor slovníku při definici termínů komi-

Benešovi. Pouze v jednom případě uvádí i zahraniční muzeology - termín sociologie muzejní pojí s Polskem a zmiňuje osobnosti J. Mikulowski-Pomorskiho, T. Banasika, T. Goluszewskiho a K. Zygulskiho.

34 BENEŠ, Josef. Muzeologický slovník. Praha: Národní muzeum - Ústřední muzeologický kabinet, 1978, s. 6-8. Jedná se o termíny archiv, archiv muzejní, archiválie a archivnictví. Odkazováno je k zákonu ČNR č. 97/1974, o archivnictví.

35 Tamtéž, s. 95. Základní dobovou normou je zákon č. 40/1956, o státní ochraně přírody.

36 Tamtéž, s. 100-102.

37 Tamtéž, s. 77. MK ČSR je ústř̌edním orgánem státní správy, zabezpečuje odbornou úroveň muzeí, organizuje poradenskou činnost (využívá poradních orgánů - Ústřední rady muzeí a galerií, Čs. výboru ICOM, Komise pro vědeckou práci). Přímá péče náleží VI. odboru ministerstva, kde je základním pracovištěm oddělení muzeí a galerií $\mathrm{VI} / 3$.

38 Tamtéž, s. 93. Věnuje se rozvoji muzejnictví v rámci kraje, řídí krajské muzeum. Přímý vliv na práci OK KNV má zákon č. 28/1972, o národních výborech.

39 Tamtéž, s. 96. Pět ústředních organizací řídí Ministerstvo kultury, krajská muzea jsou řízena KNV, okresní ONV a dále MěNV a MNV. Postavení muzeí je určeno plánem sítě muzeí v kraji.

40 Tamtéž, s. 63. Aktuálně je pojednána koncepce v Zásadách rozvoje českého muzejnictví z roku 1972.

41 Tamtéž, s. 130-131. Beneš uvádí: „Řízení muzejnictví - označení pro soubor opatření, norem a akcí, jimiž př́slušné orgány zajištují plnění společenského poslání oboru M.“ Jako hlavní odbor pro studování problémů v odvětví kultury je uváděn Ustav pro informace a řízení v kultuře, který též zajistil vydání několika Benešových monografií. se nákupní, ${ }^{42}$ nákup sbírek ${ }^{43}$ nebo vývoz předmětů muzejní hodnoty. ${ }^{44}$ Externě orientováno je i vydání periodik, některá jsou přímo pojednána, ${ }^{45}$ množství jich je zmíněno $\mathrm{v}$ rozpracovaných heslech časopisy muzejní a časopisy muzeologické. ${ }^{46}$ Následně bych rád zmínil téma muzejního managementu ${ }^{47}$ a především zpracování hesla morfologie muzea - zde Beneš velmi stručně rozebírá vnitřní uspořádání muzea, které dělí do čtyř funkcí, které ve svých teoretických pracích sám využívá. Jedná se o dokumentaci vymezeného úseku skutečnosti, ochranu a zpracování sbírek, využití pro vědu a konečně vystavování pro výchovu. ${ }^{48}$ Toliko k stručnému popisu Benešova slovníku.

Muzeologický slovník Josefa Beneše vznikl v období, kdy terminologická činnost v oblasti výkladových slovníků vrcholila. Stojí tak za pozornost věnovat se v krátkosti ještě srovnání přístupů k vybraným termínům a zaměřit ji přímo do oblasti české muzeologie. V období na přelomu 70. a 80 . let 20 . století vzniklo na našem území několik slovníků, ${ }^{49}$ kdy většina již byla výše

42 Tamtéž, s. 61, dále 109-110. Pojem uvádí jako hovorové označení pro poradní sbor pro nákupy sbírek, který je ovšem v dikcionáři též pojednán a tak se jeho zavedení dá považovat za zbytečné.

43 Tamtéž, s. 88.

44 Tamtéž, s. 163. Vývoz bývá umožněn po řízení, které je řešeno v souvislosti s vyhláškou č. 239/59 Ú. 1. o vývozu kulturních památek a předmětů kulturní hodnoty.

45 Tamtéž, s. 82. Jedná se např. o časopis Muzej ní a vlastivědná práce a knižnici Muzejní práce.

46 Tamtéž, s. 16

47 Tamtéž, s. 129-130. Jedná se o rozbor termínù ředitel muzea, řídící organ muzea a řízení muzea.

48 Tamtéž, s. 80. Beneš pojednává toto rozdělení již v jednom z prvních odborných článku z roku 1967. BENEŠ, Josef. Rozbor muzeálných funkcií. Múzeum, 1967/12, s. 22-33.

49 K porovnání chápání vybraných pojmů lze využít následující - BENEŠ, Josef. Muzeologický slovník. Praha: Národní muzeum - Ústřední muzeologický kabinet, 1978; STRÁNSKÝ, Z. Zbyněk. Úvod do studia muzeologie. Brno: Rektorát UJEP, 1980, s. 38-43; TKÁČ, Vladimír. K otázkám terminologie a tř́dění vyjadřovacích prostředků v muzejn prezentaci. Brno: Filozofická fakulta University Jana Evangelisty Purkyně, 1981. Závěrečná práce postgraduálního studia muzeologie; BENEŠ, Josef. Muzejní prezentace. Národní muzeum - Ústřední zmíněna. Vzhledem $\mathrm{k}$ tomu, že velká pozornost byla $v$ této době nejen ve slovnících věnována muzejní prezentaci, vybírám $\mathrm{k}$ popisu přímo termín „prezentace“. Jako druhou oblast volím skupinu pojmů, které se vážou $\mathrm{k}$ základům teoretické muzeologie. 50

Jako první ke srovnání je možno zvolit přímo pojem (muzejní) prezentace. Beneš ji ve svém slovníku z roku 1978 vykládá jako „označení pro teoreticky podložené způsoby výchovně vzdělávacího uplatnění sbírek speciálně pro komunikační cíle“. Rozlišuje ji na výchovnou a studijní (která je spíše pramenem vědeckého poznání). K pojmu přiřazuje blízce i další termíny - námět, libreto a scénář. ${ }^{51}$ Ve své monografii Muzejní prezentace v roce $1981^{52}$ vykládá termín ve větší šíři - zmiňuje orientaci na rozdílné kategorie návštěvníků, opět vyzvedává využití autentických/originálních předmětů. Nově rozděluje prezentaci do tří typů - památkového, muzejního a galerijního podle specifického přístupu $\mathrm{k}$ exponátům. ${ }^{53}$ Zbyněk Z. Stránský ve svých skriptech z roku 1980 prrímo s pojmem prezentace nepracuje a naopak teoreticky rozpracovává výklad pojmu komunikace do tři částí, muzejní, prezentační a druhotné. K Benešově pojetí je nejblíže samozřejmě termín prezentační komunikace. Stránský při terminologických výkladech vychází z vlastního způsobu chápání muzeologie jakožto vědeckého oboru a uvádí, že se $\mathrm{v}$ tomto případě jedná o „způsob komunikace vycházející z autenticity muzeálie jako původního, nezpro-

muzeologický kabinet, 1981, s. 347-375 (Terminologický slovníček).

50 Zde je zúženo srovnávání pouze na terminologické práce Josefa Beneše a Zbyňka Z. Stránského.

51 BENEŠ, Josef. Muzeologický slovník. Praha: Národní muzeum - Ústř̌ední muzeologický kabinet, 1978, s. 112. Termíny námět, libreto a scénář ve slovníku dále rozpracovává.

52 BENEŠ, Josef. Muzejní prezentace. Národní muzeum - Ústř̌ední muzeologický kabinet, 1981, s. 365-366. (Terminologický slovníček).

53 Tamtéž, s. 367-368. 
středkovaného zdroje poznání a hodnocení, tj. př́mého svědka dokumentované skutečnosti. “" ${ }^{44}$ Konečně Vladimír Tkáč po rozboru mnoha konkrétních vyjadřovacích prostředků popisuje muzejní prezentaci následujícím způsobem: „druh sociální komunikace charakteristický jednosměrným převážně vizuálním působením směrem $k$ návštěvníkovi realizovaným především muzeáliemi ve funkci autentických dokladi̊ určitých jevů př́rody a společnosti, přenesenými a fixovanými do určitého prostoru, zaměřený na záměrné formování lidské osobnosti." ${ }^{\text {"55 }}$

Při porovnání zmíněných přístupů se ukazuje, že Beneš ve svém Muzeologickém slovníku přistupuje $\mathrm{k}$ výkladu pojmu ve větším spojení s praxí - poukazuje srozumitelněji na vazby termínu $k$ přímé muzejní práci. Zmiňuje terminologické podchycení prezentační činnosti muzeí, rozlišuje požadavky na typy prezentací. Na druhou stranu je třeba jeho rozsáhlejší výklad pojmu (přestože dochází $\mathrm{k}$ vazbám v rámci terminologie dané oblasti) vidět obtížněji využitelný pro systematičnost terminologické práce. $\mathrm{Na}$ tu však Benešova publikace zaměřena není. ${ }^{56}$

Do skupiny pojmů, které se vážou $\mathrm{k}$ základům teoretické muzeologie, radím termíny selekce a tezaurace.

Beneš ve svém slovníku pojem selekce označuje jako „způsob a techniku vybírání dokumentačních jednotek pro výběrový soubor

54 STRÁNSKÝ, Z. Zbyněk. Úvod do studia muzeologie. Brno: Rektorát UJEP, 1980, s. 43.

55 TKÁČ, Vladimír. K otázkám terminologie a tř́dění vyjadřovacích prostředků $v$ muzejní prezentaci. Brno: Filozofická fakulta University Jana Evangelisty Purkyně, 1981, s. 21. Závěrečná práce postgraduálního studia muzeologie.

56 Obdobný podrobnější výklad shledáváme u Beneše např. u termínu exponát, který Stránský popisuje způsobem, který opět podpírá svou terminologií - „muzeálie (sbírkový predmět) vytypovaný jako komunikační prostředek" a Tkáč jej vidí jako „smyslově konkrétní prezentační prostředek" (ve své práci však exponát samozřejmě rozsáhle pojednává). dokladů.“"57 Jeho zavedení váže na Stránského jako výklad provádění aktivní muzejní dokumentace. Tímto vysvětlením se s ním však dostává do určitého sporu - nebo termín nedostatečně rozpracovává - Stránský muzejní selekci dále rozlišuje na aktivní a pasivní. Aktivní rozumí „provádění dokumentace té skutečnosti, která existuje, které jsme současníky", pasivní vidí jako vyjímání toho, co se ve skutečnosti dochovalo. Oba autoři $k$ selekci vážou i pojem dokumentace, který je rozsáhleji pojednán též ve skriptech Zbyňka Z. Stránského. ${ }^{58}$

Beneš podle uvedeného popisuje termín selekce nedostatečně, přesto se domnívám (pomineme-li, že se nesoustředí významněji na př́istup aktivní), že především popisem souvisejícího termínu dokumentace výklad, příslušný zkoumanému slovníku, ${ }^{59}$ zastřešuje.

Posledním sledovaným heslem, který tvoří podklad vědeckého pojetí muzeologie, je tezaurace. Beneš jej ve svém Muzeologickém slovníku neuvádí - lze do něj nejspíše řadit zpracování pojmů deskripce sbírkového předmětů, katalogizace a evidence sbírek. Od Stránského se zde Beneš odlišuje hlubším zpracováním, budeme-li mít na mysli slovníkové pojetí. ${ }^{60}$ Poslední vybraný termín tak do popisu pojmů z oblasti teoreticko-muzeologického přístupu ke skutečnosti tak vstupuje až později.

57 BENEŠ, Josef. Muzeologický slovník. Praha: Národní muzeum - Ústřední muzeologický kabinet, 1978, s. 134.

58 Zatímco Beneš popisuje muzejní dokumentaci jako soubor odborných činnosti, které lze dále

dělit na primární a sekundární, Stránský popisuje dokumentaci současnosti (především aktivní selekce) a dokumentaci autentickou, primární, původní a druhotnou.

59 Zde mám na mysli zejména odlišné, více prakticistní pojetí celkové problematiky. 60 Roli zde samozřejmě hraje i rozdíl v počtu zpracovaných hesel, kterých je v Benešově slovníku 410, zatímco Stránský ve svých skriptech vybírá pro výklad svého teoretického pojetí oboru jen 30 .
Muzeologický slovník Josefa Beneše, který vyšel před 40 lety, je první prací terminologického charakteru, která byla zpracována jedním odborníkem. Beneš se věnoval již od počátku 70 . let 20 . století ve svých dílčích statích problematice odlišného chápání muzejních/muzeologických termínů. Publikoval své kritické práce zejména se zaměřením na základní pojmy oboru, z nichž lze zmínit např. muzeologii, muzeografii, dokumentaci, systematiku muzejních sbírek, využití sbírek pro vědecké a výchovné činnosti nebo detailněji promýšlený termín muzejní předmět. Pozdější rozsáhlejší Muzeologický slovník byl někdy kritizován pro svou provizornost. Byl to však právě tento první český slovník, který vymezil pole diskuze o muzejní terminologii, především pak právě v české muzeologii. Zůstává i do budoucna významnou muzeologickou prací, o čemž svědčí i jeho přesah do zahraniční literatury. 169 stran se 411 zpracovanými termíny je jistě výzvou k další práci.

\section{LITERATURA:}

BENEŠ, Josef. Příspěvek k diskuzi o muzejním sbírkovém předmětu. Časopis NM-HM, 1967/2, s. 95-100.

BENEŠ, Josef. Rozbor muzeálných funkcií. Múzeum, 1967/12, s. 22-33.

BENEŠ, Josef. Muzejní, muzeální, muzeologický, muzeografický. Muzejní a vlastivědná práce, 1970/4, s. 171-172.

BENEŠ, Josef. Muzeum, muzejnictví a muzeologie. Muzejní a vlastivědná práce, 1976/4, s. 14-21.

BENEŠ, Josef. Kulturní statek, kulturní památka a muzejní předmět. Muzejní a vlastivědná práce, 1976/4, s. 90-99.

BENEŠ, Josef. Muzeum a sbírky. Praha: Ústav pro řízení a informace v kultuře, 1977.

BENEŠ, Josef. Muzeálny predmet a dokumentácia súčasnosti. Múzeum, 1977/1, s. 25-38.

BENEŠ, Josef. Muzeologický slovník. Praha: Národní muzeum - Ústřední muzeologický kabinet, 1978. 
BENEŠ, Josef. Terminologický slovník literárně muzejní komunikace. Muzejní a vlastivědná práce, 1980/1, s. 50-51. BENEŠ, Josef. Muzejní prezentace. Praha: Národní muzeum - Ústřední muzeologický kabinet, 1981.

BENEŠ, Josef. Poznámky k ujasňování povahy muzejního sbírkového předmětu. Muzejní a vlastivědná práce, 1983/2, s. 83-91.

BENEŠ, Josef. Úvod do problematiky muzeologické terminologie. Metodický zpravodaj pro vlastivědu $v$ Severomoravském kraji - Muzeologie - 10, 1986, s. 3-16.

BRŮŽA, Oskar. Př́spěvky k sjednocování oborové terminologie. Brno: Filozofická fakulta University Jana Evangelisty Purkyně, 1978. Závěrečná práce postgraduálního studia muzeologie.

BRŮŽA, Oskar a Zbyněk Z. STRÁNSKÝ. Kleines Wörterbuch des Museumswesens. Muzeologické sešity VI/76, 1976, s. 207-212.

BRŮŽA, Oskar a Zbyněk Z. STRÁNSKÝ. Zrod muzejní terminologie. Muzeologické sešity X/86, 1986, s. 137-172.
BURCAW, G. Ellis. Introduction to Museum Work. Nashville: American Association for State and Local History, 1975.

Dictionarium Museologicum. Budapest: Hungarian Esperanto Association, 1986.

Kleines Wörterbuch des Museumswesen. Berlin: Institut für Museumswesen, 1975.

Kratkij slovar muzejnych terminov. Moskva, 1974.

Museological terminology. In MENSCH, Peter van. Towards a methodology of museology. Zagreb: University of Zagreb, 1992. $\mathrm{PhD}$. thesis [online]. [cit. 2018-06-20]. Dostupný z www: < http://vana.muuseum.ee/uploads/files/mensch08.html>.

Metodický list M/1/1978. Brno: Moravské muzeum v Brně, 1978.

Moscow 1977: 12th General Assembly of ICOM. Moscow, USSR, 28 May 1977. In ICOM International Council of Museums [online]. ICOM 2010-2018 [cit. 201806-20]. Dostupný z www: <http:// icom.museum/the-governance/generalassembly/resolutions-adopted-byicoms-general-assemblies-1946-to-date/ moscow-1977/>.
Newsletter of Museological Terminology. 1979-1986.

Pojmoslovie literárnomúzejnej komunikácie. Dolný Kubín - Nitra, 1979.

SCHREINER, Klaus. Museologische TerminiAuswahl. Neubrandenburg, 1982.

STRÁNSKÝ, Z. Zbyněk. G. E. Burcaw: Introduction to Museum Work. Muzeologické sešity VII/79, 1979, s. 152-154.

STRÁNSKÝ, Z. Zbyněk. Úvod do studia muzeologie. Brno: Rektorát UJEP, 1980.

ŠULEǨ, Petr. J. Beneš: Muzeologický slovník. Muzeologický sešity VII/79, 1979.

TKÁČ, Vladimír. K otázkám terminologie a tř́dění vyjadřovacích prostředků $v \mathrm{mu}$ zejní prezentaci. Brno: Filozofická fakulta University Jana Evangelisty Purkyně, 1981. Závěrečná práce postgraduálního studia muzeologie.

\section{VÁCLAV RUTAR}

Národní technické muzeum, Praha, Česká republika 